\title{
Clinical impact of novel treatment strategies
}

\author{
Giuseppe Giaccone*,1 \\ ${ }^{1}$ Division of Medical Oncology, Vrije Universiteit Medical Center, Amsterdam, The Netherlands
}

Following two decades of research on the biology of cancer and in particular of lung cancer, we have now a large number of molecular targets that can be utilized to create specific medicines against these cancers. Non-small cell lung cancer represents numerically the most important solid tumor in Western world, and is poorly affected by current therapies, where surgery represents almost the only curative therapy for about $25 \%$ of patients who are resectable at diagnosis. An abundant number of targeted therapies are being investigated in NSCLC. Among them are the metalloproteinase inhibitors, several tyrosine kinase inhibitors and several attempts of gene replacement have also been made. Promising results have so far been obtained with some of these approaches, and the outcome of large randomized studies is awaited. Small cell lung cancer (SCLC) represents about $20 \%$ of lung carcinomas, and several of the novel approaches that are being attempted for NSCLC, are also being investigated for SCLC. All these novel therapies open a new era of anticancer treatment that will likely complement the currently available therapies in the near future.

Oncogene (2002) 21, 6970-6981. doi:10.1038/sj.onc. 1205565

Keywords: lung cancer; targeted therapy; growth hormones

\section{Introduction}

Non-small cell lung cancers (adenocarcinoma, squamous cell carcinoma, large cell anaplastic carcinoma and undifferentiated carcinomas) represent approximately $80 \%$ of all lung carcinomas. Surgery is the mainstay therapy of resectable cases of non-small cell lung cancer (NSCLC), but only a quarter of patients undergo successful operation, and more than $50 \%$ of them will eventually recur. Chemotherapy, although broadly used in advanced disease, improves survival only marginally, at the cost of substantial toxicity. Even after the introduction of a series of novel chemotherapeutic agents in the last decade, improvement of outcome is still very limited, and it appears that chemotherapy has reached a plateau.

Small cell lung carcinomas (SCLC) are treated by chemotherapy, which achieves major responses in over

\footnotetext{
*Correspondence: G Giaccone, Division of Medical Oncology, Vrije Universiteit Medical Center, 1117 De Boelelaan, HV 1081, Amsterdam, The Netherlands; E-mail: G.Giaccone@vumc.nl
}

$50 \%$ of patients, even with extensive disease at presentation. For patients with limited disease, combined chemotherapy and radiotherapy are the treatment of choice, and early and concomitant radiotherapy appears to achieve better results than sequential chemotherapy followed by radiotherapy to the chest. Prophylactic cranial irradiation reduces the risk of brain metastases and improves survival in patients who complete remission. In the past 20 years small improvements in the prognosis have been achieved. Recently the introduction of irinotecan was shown to improve survival of patients with extensive disease compared to the standard of cisplatin and etoposide (Noda et al., 2002).

The growth of basic understanding of the biology of cancer and of lung cancer in particular has been explosive in the past two decades and is now beginning to pay off. Indeed, continued progress in our understanding of lung cancer biology has revealed numerous potential therapeutic targets (Carbone, 1997; Forgacs et al., 2001). Inhibition of growth factors, interference with abnormal signal transduction or inhibition of angiogenesis represent some of the many potential therapeutic targets available for study. This review will only deal with the compounds that have been specifically tested in NSCLC and in SCLC.

\section{Anti-angiogenesis}

The growth of solid tumors is dependent on angiogenesis, the formation of new blood vessels (Ferrara and Bunting, 1996). Several angiogenic factors have been identified, including Vascular endothelial growth factor (VEGF) and basic Fibroblast Growth Factor (bFGF), which are responsible for stimulating new blood vessel formation (Folkman, 1995). However, tumors also stimulate endogenous inhibitors of angiogenesis (Chen et al., 1995), which include angiostatin (O'Reilly et al., 1994), endostatin (O'Reilly et al., 1997), and thrombospondin (Good et al., 1990). The angiogenic process is regulated by the balance of angiogenic inducer activity over angiogenic inhibitor activity.

VEGF, an endothelial cell-specific mitogen, is a major regulator of angiogenesis (Ferrara and Bunting, 1996; Ferrara, 1999) and the receptors for VEGF, flt-1 and $f(k-1 / K D R$, are specifically expressed on the cell surface of endothelial cells. Antibodies against VEGF and small molecules against the VEGF receptor are being tested in NSCLC and other tumor types.

Anti-VEGF antibodies can suppress the growth of a variety of tumor cell lines in nude mice and can also 
inhibit angiogenesis in animal models of intra-ocular neovascularization (Ferrara and Bunting, 1996).

Table 1 summarizes ongoing studies with angiogenesis inhibitors in NSCLC patients. No studies so far are running for SCLC.

In human studies, an anti-VEGF rhuMoAb has been administered with minimal side effects alone and in combination with chemotherapy (Gordan et al., 1998; Margolin et al., 1999). Side effects associated with antiVEGF antibodies include headache, asthenia, lowgrade fever, nausea and vomiting, arthralgias, cough, dyspnea and skin rash. Three episodes of tumor-related bleeding were observed in these initial studies (Gordan et al., 1998). The results of phase I trials led to the conduct of a randomized phase II study in NSCLC and other solid tumors, in which two dose levels of anti-VEGF $(7.5 \mathrm{mg} / \mathrm{kg}$ vs $15 \mathrm{mg} / \mathrm{kg})$ plus chemotherapy were compared to chemotherapy alone (DeVore et al., 2000). In this chemotherapy alone arm, therapy with the VEGF antibody was allowed upon progression. In the NSCLC study chemotherapy consisted of carboplatin and paclitaxel given at full doses (AUC of six and $200 \mathrm{mg} / \mathrm{m}^{2}$ every 3 weeks, respectively). Patients treated with the higher dose of anti-VEGF experienced a prolonged time to tumor progression compared to chemotherapy alone or chemotherapy plus the lower dose of anti-VEGF (129 days vs 131 days vs 225 days). Median survival was 56.8 weeks in the control group and 49.9 weeks and 61.5 weeks in the low- and high-dose anti-VEGF arms, respectively. The survival in all three arms of this study are impressive, as the majority of the patients enrolled were stage IV patients, where a survival of 8 months may be expected. It is postulated that the apparently improved results for the control arm might be explained, at least in part, by a crossover to single agent anti-VEGF upon disease progression (Johnson et al., 2001). Although the toxicity in this study was mainly characterized by chemotherapy-related side effects, six patients experienced life-threatening hemoptoes, four of which were fatal. Remarkably, the fatal hemorrhages were most common in patients with squamous histology and centrally located tumors. Furthermore, several episodes of non life-threatening epistaxis were also observed in this study, in the two arms containing the anti-VEGF rhuMoAb (31\% and $44 \%$ in the low vs high dose arms, respectively). Increase arterial blood pressure was also observed in the combined arms. Although the overall incidence of life-threatening hemorrhage was substantial $(9 \%)$, it was relatively modest among those patients with non-squamous histology. When the squamous carcinoma patients are excluded from the survival analysis the results appeared very promising. Among the 78 patients entered with non-squamous cell carcinoma histology the median survivals were 53 weeks, 61 weeks, and 77 weeks, respectively in the chemotherapy alone, the low- or high-dose anti-VEGF, respectively (Johnson et al., 2001). Based upon these new data, ECOG initiated a phase III study of chemotherapy plus high-dose $(15 \mathrm{mg} / \mathrm{kg})$ anti-VEGF versus chemotherapy alone in advanced, non-squamous NSCLC. In this study no cross-over to the VEGF antibody is allowed upon progression in the chemotherapy alone arm.

Another anti-angiogenic drug under active investigation is SU5416, a synthetic compound that is a specific VEGF receptor (flk-1) antagonist (Fong et al., 1999). Although the drug has no direct anti-tumor effects, in vitro biochemical assays of SU5416 have demonstrated its ability to inhibit Flk-1 receptor phosphorylation that follows the binding of the VEGF ligand with its receptor. In addition, SU5416 inhibits in vitro proliferation of endothelial cells induced by VEGF. In preclinical models, SU5416 was shown to have a broad anti-tumor activity in tumor xenografts in nude mice, including lung carcinoma lines (Fong et al., 1999; Mendel et al., 2000). The drug appears to be relatively well tolerated, with dose-limiting side effects including headache and projectile vomiting; other toxicities observed in the phase I study were diarrhea, nausea, anorexia, abdominal pain, constipation, asthenia, severe phlebitis requiring central venous administration in several cases, and allergic reactions. In addition thrombotic episodes have been observed (Rosen et al., 1999). A number of Phase I/II studies in combination with chemotherapy have been performed. Because of its inhibition of the stem cell factor receptor (c-kit) (Smolich et al., 2001), SU5416 is also being evaluated with interest in SCLC. In a feasibility study SU5416 was administered at two different doses in combination with full doses of cisplatin and gemcitabine. In this study, besides the expected side effects observed with chemotherapy and with SU5416 alone, a worrying increase of thromboembolic events were observed. In a total of 19 patients enrolled, with several different malignancies, 9 thromboembolic events were recorded

Table 1 Clinical studies with angiogenesis inhibitors in NSCLC

\begin{tabular}{|c|c|c|c|}
\hline Drug & Mechanism & Status & Trial design \\
\hline RhuMab VEGF & VEGF-antagonist & phase III & $\begin{array}{l}\text { carboplatin/paclitaxel } \pm \text { compound, no } \\
\text { cross-over, non-squamous }\end{array}$ \\
\hline Thalidomide & TNF $\alpha$-antagonist & phase I & with carboplatin/paclitaxel \\
\hline Thalidomide & $\mathrm{TNF} \alpha$-antagonist & phase III & $\begin{array}{l}\text { carboplatin/paclitaxel followed by } \\
\text { radiation } \pm \text { compound in stage III NSCLC }\end{array}$ \\
\hline SU5416 & $\begin{array}{l}\text { inhibitor of VEGF-mediated Flk-1 receptor } \\
\text { signaling }\end{array}$ & phase I & with carboplatin/paclitaxel \\
\hline SU5416 & inhibitor of VEGF-mediated Flk-1 receptor & phase I, closed & with cisplatin/gemcitabine \\
\hline Squalamine & inhibits sodium-hydrogen exchanger, NHE3 & phase II/III & with chemotherapy and with chemo-radiation \\
\hline
\end{tabular}


in eight patients. The explanation of these effects is still unclear, but may involve disturbances in the coagulation cascade and interaction with endothelial stability (Kuenen et al., 2002).

Thalidomide, first marketed in Europe in the late 1950 s as a non-barbiturate hypnotic for insomnia (Adlard, 2000), was withdrawn from the market in early 1960s due to its teratogenic effects. Although the mechanism of its anti-angiogenic effect is still largely unknown, thalidomide inhibits vascularization induced by bFGF in rabbit corneal micropocket model by $30-$ $50 \%$ after only two doses (Bauer et al., 1998), and it inhibits bFGF- and VEGF-induced neovascularization in mouse corneal model (Kenyon et al., 1997).

These results have prompted the study of thalidomide in a number of tumor types (Adlard, 2000; Thomas and Kantarjian, 2000). Following the significant activity observed in refractory myeloma, in which $32 \%$ of previously treated patients had a paraprotein response (Singhal et al., 1999), a phase III study was started by the Eastern Cooperative Oncology Group of neoadjuvant chemotherapy and thoracic radiation therapy with or without thalidomide in locally advanced NSCLC. Patients with unresectable Stage IIIA or IIIB disease without significant pleural effusion receive two cycles of paclitaxel/carboplatin, followed by thoracic radiotherapy, with or without thalidomide. Patients on the thalidomide arm who have had a response or stable disease continue on thalidomide until progression or for a total of 24 months.

Several other anti-angiogenesis agents are being developed, among which some may show promise and are likely to be tested in the future also in advanced NSCLC. A major problem for the development of these agents however appears to be present, being the fact that no substantial antitumor activity can be seen with these agents when given alone in patients with solid tumors. In order to prove that stabilizations of disease have any impact on survival, early initiation of randomized studies is necessary and this slows down the development of these agents. Another important aspect for the development of these agents is that they do have toxicities, which are different and mainly non-overlapping with those of chemotherapy, but nonetheless may be severe. Proper feasibility studies with chemotherapy are necessary in specific patient populations, before embarking in large randomized studies.

\section{Matrix metalloproteinase inhibitors (MMPI)}

In the process of neoangiogenesis metalloproteases enzymes are necessary. These enzymes are primarily involved in the remodeling of tissues and in particular of tumor growth with respect to the surrounding extracellular matrix. The process of tumor invasion and metastasis relies on the production and release of MMPs by the tumor cells and other cells surrounding the tumor cells, such as fibroblasts. Tumor growth requires breakdown of the epithelial basement membrane, and invasion through underlying connective tissue. Metastasis involves further invasion of tumor cells through the basement membrane of blood vessels and lymphatics, followed by lymphatic and hematogenous dissemination, and finally, parenchymal invasion of distant organs. Active proteolysis of matrix constituents is necessary for each of these steps to occur (Parsons et al., 1997; Stetler-Stevenson et al., 1996; Chambers and Matrisian, 1997).

Matrix metalloproteinases (MMP) are a family of at least 20 zinc-containing endo-proteinases capable of degrading collagen and proteoglycan. There is a positive correlation between tumor aggressiveness and protease secretion. In particular, the involvement of MMP-2 (gelatinase A) and MMP-9 (gelatinase B) is well documented in breast, ovarian, colorectal and lung tumors. Interference with the activity of MMPs through the expression of endogenous tissue inhibitors of MMPs (TIMPs) has been shown to inhibit invasion in vitro and in vivo and to block tumor-induced neovascularization.

MMP-2 and MMP-9 are particularly expressed in human NSCLCs by tumor cells and tumor-associated stromal cells and their expression is correlated with pathologic invasiveness as defined by the presence of lymph node metastasis (Brown et al., 1993; Clarke et al., 1997).

Inhibitors of MMPs have been developed and several of them tested in advanced NSCLC and other solid tumors in advanced stages of the disease. Among these MMPIs the following have been investigated in lung cancer: Prinomastat (AG3340; Agouron), BAY12-9566 (Bayer), Batimastat (British Biotech), Marimastat (British Biotech), and BMS-275291 (Bristol) (Nelson et al., 2000). The side effect profiles of these agents are similar and include proximal musculoskeletal pain, arthralgias and stiffness. BAY12-9566, however, is structurally distinct from other MMPIs. It is a butanoic acid analog and highly protein bound. It has essentially no action upon interstitial collagenases, which may account for its selectivity as well as its different toxicity profile, which does not include the musculoskeletal problems but has been associated with an asymptomatic rise in hepatic enzymes and thrombocytopenia.

Despite the preclinical data demonstrating an antitumor effect of MMPIs either as single agents or in combination with chemotherapy, however, MMPIs have not demonstrated to have therapeutic potential in human lung cancer. The studies performed in lung cancer are summarized in Table 2. In a large randomized phase III study conducted in advanced NSCLC, prinomastat (AG3340) was combined with paclitaxel and carboplatin in chemotherapy naïve patients (Smylie et al., 2001). A total of 686 patients were randomized to twice daily prinomastat $(5,10$ or $15 \mathrm{mg}$ ) or placebo. Unfortunately, no differences were observed among the treatment arms in overall or 1 year survival, progression-free survival or response rate (Smylie et al., 2001). Toxicities were however more frequent in the prinomastat containing arms and were more severe in the higher prinomastat dose arms. A 
Table 2 Metalloproteinase inhibitors (MMPIs) assessed in lung cancer

\begin{tabular}{|c|c|c|c|}
\hline Drug & Mechanism & Status & Trial design \\
\hline Marimastat & inhibits MMP-1, 8 and 13 & phase III & $\begin{array}{l}\text { patients with minimal residual disease NSCLC after } \\
\text { chemotherapy, radiotherapy and/or surgery: compound } \\
\text { vs placebo }\end{array}$ \\
\hline Marimastat & MMPI, inhibits MMP-1, 8 and 13 & phase III, completed & $\begin{array}{l}\text { patients with SCLC in response after chemotherapy, } \\
\text { radiotherapy: compound vs placebo }\end{array}$ \\
\hline Prinomastat & inhibits MMP-2, 3 and 13 & phase III & $\begin{array}{l}\text { cisplatin/gemcitabine }+ \text { compound } v s \\
\text { cisplatin/gemcitabine }+ \text { placebo in advanced NSCLC }\end{array}$ \\
\hline $\begin{array}{l}\text { Prinomastat } \\
(\mathrm{AG} 3340)\end{array}$ & inhibits MMP-2, 3 and 13 & phase III, completed & $\begin{array}{l}\text { carboplatin/paclitaxel }+ \text { compound } v s \\
\text { carboplatin/paclitaxel }+ \text { placebo in advanced NSCLC }\end{array}$ \\
\hline BMS-275291 & broad-spectrum MMPI & phase III & $\begin{array}{l}\text { carboplatin/paclitaxel + compound } v s \\
\text { carboplatin/paclitaxel }+ \text { placebo in advanced NSCLC }\end{array}$ \\
\hline
\end{tabular}

phase III study of carboplatin-paclitaxel with BMS275291 or placebo in previously untreated advanced NSCLC patients is being run by the NCI-Canada group, after demonstration of safety (Smylie et al., 2001). This study is presently approaching completion.

In SCLC a phase III study involving the Bayer compound plus chemotherapy in limited stage patients was terminated early when an interim analysis revealed the arm containing the study drug in addition to chemotherapy had an inferior survival when compared to the chemotherapy plus placebo arm (unpublished data). Marimastat maintenance also failed to show a survival advantage when studied in patients with SCLC who responded to induction therapy (Shepherd et al., 2001). This was a large study of over 500 patients with limited or extensive disease SCLC conducted by NCICanada and EORTC. Patients were randomized to receive marimastat orally at $10 \mathrm{mg}$ bid or placebo for 2 years, if they had achieved a complete or partial remission after chemotherapy or chemo-radiotherapy. Survival and progression-free survival were identical in the two arms of the study, but specific side effects, known to be due to MMP inhibitors, such as arthralgia, myalgia and bone pain were all significantly more common and severe in the marimastat arm. This led to an inferior quality of life, as assessed using the EORTC QoL questionnaire, and a poorer compliance to the therapy in the marimastat arm.

Neovastat (Æ-941), an aqueous extract derived from shark cartilage that has anti-VEGF and metalloproteinase inhibitory activity, exhibits antitumor and antimetastatic activity in human tumor xenografts. In two phase I/II safety trials, Neovastat was evaluated as monotherapy or in combination with chemotherapy in patients with various solid tumors. The most frequent adverse events were nausea $(7 \%)$, vomiting $(3 \%)$, dyspepsia $(2 \%)$, and anorexia $(2 \%)$. A phase II trial of AE-941 in addition to combined modality treatment (CT/XRT) in locally advanced stage IIIB NSCLC is ongoing. Phase III randomized, double-blind trials are also under way.

\section{Inhibitors of the ErbB receptor family}

There is considerable evidence that Receptor Tyrosine Kinases (RTKs) are important in human cancers
(Levitzki and Gazit, 1995). RTKs such as erbB (EGF receptor), neu (HER2), kit (stem-cell factor receptor), met (HGF receptor) and others are oncogenes when activated by gene alterations or inappropriately expressed (Shawver, 1999). These RTKs serve as potential therapeutic targets in solid tumors including lung cancer (Levitzki and Gazit, 1995; Ichimura et al., 1996; Giatromanolaki et al., 1996; Olivero et al., 1996; Kim et al., 1998; Nemunaitis et al., 1998; Guddo et al., 1999).

The ErbB family of RTKs includes four distinct members: HER1 (EGFR or c-erbB-1), HER2 (neu or c-erbB-2), HER3 (c-erbB-3), and HER4 (c-erbB-4). All but HER3 possess intrinsic tyrosine kinase activity. The homology among the members of the ErbB family of receptors is high, in particular for what concerns the tyrosine kinase domain, whereas larger differences are present in the extracellular domains and in the intracellular C-terminus domain, which is responsible for the diversified stimulation of downstream signal transduction pathways (Arteaga, 2001). The EGFR is a $170 \mathrm{kDa}$ transmembrane glycoprotein that is encoded by the c-erbB-1 proto-oncogene (Carpenter, 1987; Carpenter and Cohen, 1990). Unlike the other HER subfamily members, HER2 is not strictly a receptor since it appears to respond to no high-affinity endogenous ligand and acts instead as a signaling network coordinator and amplifier when it heterodimerizes with other HER family members (Klapper et al., 1999). Growth factors/ligands for these receptors include EGF, growth hormone growth factor, plateletderived growth factor (PDGF) for the EGFR; heregulin, EGF, PDGF, tumor growth factor (TGF) for the HER2 receptor; insulin for the HER3 receptor; and the heregulin $\alpha$ and $\beta$ proteins for the HER4 receptor (Salomon et al., 1995; Yarden and Ullrich, 1988).

Several EGFR inhibitors are being developed, most are small molecules, which inhibit the tyrosine kinase activity by competing with the ATP binding site, and many others are monoclonal antibodies directed at the extracellular domain of the protein. A summary of studies in lung cancer with ErbB inhibitors is given in Table 3. As overexpression of both EGFR and Her2/ neu is far more important for NSCLC than SCLC, all studies are targeting NSCLC, mainly in advanced stages of the disease. 
Table 3 Current randomized trials with EGFR inhibitors in advanced NSCLC

\begin{tabular}{llll}
\hline & Compound & Status & Design of study \\
\hline $\begin{array}{l}\text { Small } \\
\text { molecules }\end{array}$ & $\begin{array}{l}\text { ZD1839 } \\
\text { (Iressa) }\end{array}$ & $\begin{array}{l}\text { Phase III, } \\
\text { completed }\end{array}$ & $\begin{array}{l}\text { Carboplatin/paclitaxel }+ \\
\text { Iressa (two different doses) } \\
\text { or placebo }\end{array}$ \\
& $\begin{array}{l}\text { ZD1839 } \\
\text { (Iressa) }\end{array}$ & $\begin{array}{l}\text { Phase III, } \\
\text { completed }\end{array}$ & $\begin{array}{l}\text { Cisplatin/gemcitabine }+ \\
\text { Iressa (two different doses) } \\
\text { or placebo } \\
\text { Chemotherapy }+ \text { OSI 774 vs } \\
\text { chemotherapy + placebo } \\
\text { Failures after } 1-2 \text { regimens: } \\
\text { OSI-774 vs placebo }\end{array}$ \\
\hline
\end{tabular}

There are at least two EGFR tyrosine kinase inhibitors, small molecules, which are in current clinical development for NSCLC, ZD1839 (Iressa, AstraZeneca) and OSI-774 (Tarceva ${ }^{\mathrm{TM}}$, Genentech/Roche/OSI Pharmaceutical) (Traxler et al., 1999; Bos et al., 1997; Baselga and Averbuch, 2000; Hidalgo et al., 2001). A novel pan-erbB TKI (CI-1033, Pfizer) is in earlier phases of clinical development, and will soon also be investigated in advanced NSCLC in combination with chemotherapy (Shin et al., 2001). A dual inhibitor of EGFR and Her2 is also approaching phase II and phase III studies (GW2016, Glaxo-SKB). The latter two molecules may have the advantage of having a broader spectrum of activity and of covering the issue of heterodimerization between different members of the ErbB family of receptors.

In both US, European and Japanese phase I studies, ZD1839 has demonstrated single agent activity in previously heavily treated NSCLC patients with several objective responses (Kris et al., 2000; Negoro et al., 2001). Definite activity has also been observed with OSI-774 (Perez-Soler et al., 2001). Both compounds are well absorbed orally and can be given chronically. Both ZD1839 and OSI-774 are generally well tolerated; their major toxicities are diarrhea and an acneiform skin rash. These side effects are dose dependent and diarrhea is dose-limiting. Other side effects include nausea, and transient transaminitis. All these side effects are reversible upon suspension of treatment. In general, no myelosuppression is observed when these agents are used alone, which makes particularly appealing their combination with chemotherapy. The combination of EGFR TKIs with various cytotoxic agents demonstrated additive or synergistic activity against a variety of human tumor xenografts in preclinical studies (Sirotnak et al., 2000; Ciardiello et al., 2000), and thus these agents have been used in combination with chemotherapy early on in clinical studies in humans. Combination of Iressa with paclitaxel and with platinum compounds have shown synergy in some preclinical models (Sirotnak et al., 2000; Ciardiello et al., 2000). Phase II data are now available with both Iressa and OSI-774. Iressa was tested in 210 patients with advanced NSCLC who had received one or two prior regimens; patients were randomized to receive 250 or $500 \mathrm{mg}$ Iressa daily, until progression. Approximately $40 \%$ of patients experi- enced symptom improvement and the response rate was $18.5 \%$, without major difference between second and third line therapy. Grade 3-4 adverse events were more frequent in patients receiving the higher dose Iressa, but the response rate was comparable, suggesting that activity is achieved at a dose of $250 \mathrm{mg}$, and higher doses do not produce better efficacy but only increased toxicity (Baselga et al., 2001). OSI-774 was tested in 56 advanced NSCLC patients who failed prior platinum-based chemotherapy. OSI-774 was given at a fixed dose of $150 \mathrm{mg} /$ day continuously, and, unlike the studies with Iressa, patients included in this study were selected based on overexpression of EGFR $(\geqslant 10 \%$ positive cells). In this study almost $80 \%$ of patients experienced acneiform rash, and the response rate was $12.5 \%$ (Perez-Soler et al., 2001).

Based on these interesting results, two large randomized studies with chemotherapy and Iressa have been recently completed. The design of these studies was that of a three-arm trial in which chemotherapy was given in addition to Iressa $500 \mathrm{mg} /$ day, or Iressa $250 \mathrm{mg} /$ day, or placebo, in a double blinded fashion. The oral medication (Iressa or placebo) was continued after termination of chemotherapy, until progression. The two studies employed two different chemotherapy regimens: carboplatin-paclitaxel, which is standard in North-America, and cisplatin-gemcitabine, which is more frequently employed in other parts of the world, including Europe. Both studies accrued over 1100 patients and the final analysis is expected shortly. Phase III trials of similar design are underway using OSI-774. The results of these important trials will help define the role of these new agents in management of advanced NSCLC.

Furthermore, many additional studies are about to start with Iressa in earlier stages of NSCLC, including in stage IIIB and in the adjuvant setting of radically resected tumors. Furthermore studies are also being planned in the chemopreventive setting, in patients who had a smoke-related primary cancer and who are at risk of developing lung cancer as a secondary cancer (early stage NSCLC, head and neck cancer, limited disease SCLC, bladder cancer, esophageal cancer) (Averbuch, 2002). Patients will be evaluated with repeat bronchoscopies, investigating changes in several biological markers.

Of the antibodies directed against the extracellular domain of EGFR, certainly IMC-C225 (C225, Cetuximab) is certainly the one in most advanced stages of development. C225 is a human:murine chimeric antiEGFR IgG1 monoclonal antibody that competes with EGF for binding to the EGFR and inhibits EGFinduced tyrosine kinase-dependent phosphorylation (Ennis et al., 1989). Antitumor efficacy of IMC-C225 results from multiple mechanisms that include inhibition of cell cycle progression, promotion of apoptosis, anti-angiogenesis, and potential enhancement of immunologic activity (Herbst et al., 2001). Further, IMCC225 may reduce metastasis formation by downregulating the expression of matrix metalloproteinases (O-Charoenrat et al., 2000). 
C225 has been evaluated very early in the development of this agent in combination with chemotherapy. $\mathrm{C} 225$ is given intravenously every week at $250 \mathrm{mg} / \mathrm{m}^{2}$ after a loading dose of $400 \mathrm{mg} / \mathrm{m}^{2}$. C225 has been administered alone and in combination with chemotherapy and radiation therapy in more than 750 patients. Overall, C225 is well tolerated: most adverse events of C225 alone were mild to moderate, and only $12 \%$ were considered to be grade 3 or 4 in severity. Allergic reactions and acne-like rashes were the most clinically important adverse events. Out of the 89 patients evaluated, eight $(4 \%)$ had grade $3-4$ allergic reactions; all patients however, recovered after empiric therapy (Cohen et al., 2000). In contrast to the small molecules inhibiting EGFR, monoclonal antibodies against do not appear to produce significant diarrhea due to their inability to cross into the lumen of the gastrointestinal tract after intravenous administration. A fully humanized antibody (EMD72000) is also being developed by Imclone, that should be relatively devoid of the allergic reactions. Another fully human antibody against EGFR (ABX-EGF) will soon enter clinical study and is being co-developed by Abgenix and Immunex (Figlin et al., 2001; Yang et al., 2001).

Based on very promising results obtained in advanced squamous cell carcinoma of the head and neck (Baselga et al., 2000; Perez-Soler et al., 1998), in combination with cisplatin or radiotherapy, phase II/ III studies were initiated and are ongoing in patients with metastatic, recurrent, or locoregionally advanced head and neck cancer. Also based on a large phase II study of Cetuximab in irinotecan-refractory colorectal patients a large randomized study has been initiated in this setting (Herbst et al., 2001). Unlike most studies performed with TKIs against the EGFR, all studies performed with Cetuximab selected patients based on overexpression of the receptor, as this may greatly influence the binding of the monoclonal.

Although C225 alone inhibits growth in high EGFRexpressing NSCLC cells, clinical trials for IMC-C225 in NSCLC have not been reported as yet. However, it is expected to have some activity by itself and in combination with chemotherapy and/or radiation. Phase II trials using IMC-C225 with chemotherapy in advanced lung cancer are just getting underway.

Among the antibodies developed against the ErbB family of receptors, much further in development in lung cancer is Trastuzumab (Herceptin ${ }^{\circledR}$ ), a chimerized monoclonal antibody against HER2 (c-erbB-2) developed by Genentech. As HER2 is frequently overexpressed in NSCLC and appears to be associated with drug resistance, increased metastatic potential, increased production of vascular endothelial growth factor, and poor prognosis (Tsai et al., 1993, 1995; Kern et al., 1990, 1994; Yu et al., 1994; Zeng-Rong et al., 1995; Pietras et al., 1994, 1999). Combining trastuzumab with chemotherapy results in enhanced cytotoxicity in preclinical models (Arteaga et al., 1994; Fan et al., 1993; Baselga et al., 1998).

In an ECOG study trastuzumab was administered with carboplatin plus paclitaxel to untreated patients with advanced NSCLC in a phase II trial (Human gene marker/therapy controls, 1999). Eligible patients were enrolled provided they had any level of HER2 expression (i.e., $1+-3+$ ) as assessed by the commercially available Herceptest ${ }^{\circledR}$. Out of the 139 patients screened for entry, 50 were HER2 negative, and only $13(9 \%)$ were $3+$. Fifty-six patients eventually received therapy, and out of the 51 evaluable for response nine $(18 \%)$ demonstrated an objective response. The median survival time was 9.8 months and five out of eight HER2 $3+$ patients were still alive at more than 1 year of follow-up (Langer et al., 2001).

HER2 overexpression in non-small cell lung cancer was less common in the study conducted at Memorial Sloan Kettering Cancer Center (Krug et al., 2001). Among the 84 patients screened, HER2 was $3+$ in six patients only, and $20 \%$ of patients overexpressed HER2 (i.e., 2-3+). In this phase II trial patients received trastuzumab with either docetaxel or paclitaxel. The overall response rate was $26 \%$ and was not different according to HER2 status (overexpression $=25 \%$ vs non-overexpression $=24 \%$ ) nor was there a differential response according to taxane used $($ paclitaxel $=26 \%$; docetaxel $=23 \%)($ Abelda, 1997) . At the time of the initial presentation, median survival had not been reached. However, it appears the survival of the HER2 $(+)$ patients was inferior to that of their HER2 negative counterparts.

In a randomized phase II study in previously untreated NSCLC 103 patients were randomized to receive cisplatin-gemcitabine or cisplatin-gemcitabine and trastuzumab (Gatzemeier et al., 2001). Only patients overexpressing Her2/neu were entered, and this was defined as immunohistochemistry $2+$ or $3+$, positive FISH or high serum levels of the shed extracellular domain of Her2. There were essentially no differences in side effects, response rate, time to progression and survival between the two arms. Although this study was not powered to demonstrate a difference in survival endpoints, there was no suggestion that trastuzumab added any activity to this combination chemotherapy. Interestingly, if only the Her $3+$ cases were considered, they compared relatively more favorably compared to the rest of patients.

It would therefore appear that the highly overexpressing Her2 cases are relatively infrequent in NSCLC, as amplification is a rare event in this disease, compared to breast cancer. This may make the patient selection process rather cumbersome and impossible to run large randomized studies in this disease. The use of the antibody in patients not highly overexpressing Her2 does not seem to have activity.

Several other tyrosine kinase inhibitors are under development for hematological malignancies and solid tumors, including lung cancer. The impressive results obtained with STI-571 (Glivec ${ }^{\mathrm{TM}}$, Novartis) in chronic myeloid leukemia and gastrointestinal stromal tumors (GIST) have engendered tremendous enthusiasm for the small molecular RTKIs in other solid tumors including small cell and non-small cell lung cancers (Wang et al., 2000; Druker et al., 2001a,b; Blanke et 
al., 2001). Given the high expression of c-kit in SCLC, which is targeted by STI-571, has led to a phase II study of this drug alone and in combination with chemotherapy. Results are eagerly awaited.

\section{Gene therapy}

Cancer is a disease of the genes, and in lung cancer there are lots of genes which are irreversibly altered. Mutations in oncogenes and tumor repressor genes are responsible for defective ability of tumors to undergo programmed cell death and for uncontrolled cell proliferation. The restoration of the normal function of specific genes is particularly appealing as a treatment modality. There are essentially two major ways of using genes as a therapeutic: one is to insert a wild type gene, in order to revert the altered properties of a mutated gene (e.g. p53), the other is to switch off a gene which is aberrantly active due to a mutation, by for instance antisense oligonucleotides (e.g. K-ras).

The recessive oncogene p53 is located on the chromosomal region $17 \mathrm{p} 13$ and one allele is frequently mutated in both SCLC and NSCLC, and mutational inactivation of the remaining allele occurs in more than $90 \%$ of SCLC and 50 percent of NSCLC (Carbone, 1997; Forgacs et al., 2001). The reintroduction of a wild type p53 gene into lung cancer cells which have mutated p53, dramatically inhibits tumor cell growth and promotes tumor cell death. Restoration of wildtype p53 function in the cancer cell by gene transfer is sufficient to cause either cell-cycle arrest or apoptosis (Nguyen et al., 1997).

Investigators at MD. Anderson conducted the first gene transfer study in locally advanced NSCLC with encouraging results (Roth et al., 1996). In this first study a retroviral vector containing the wild-type p53 gene was injected directly into the locally advanced bronchial tumor of nine patients, all of which had failed conventional therapies. Local tumor regression was observed in three tumors and three other tumors displayed stabilization. Importantly, no clinically significant vector-related toxic effects were reported. Expression of wild-type p53 was detected in posttreatment biopsies, indicating the successful transfection; furthermore, apoptosis was more frequent in post-treatment biopsies than in pretreatment biopsies.

The same group then performed another study using adenoviral vectors, instead of retroviral vectors. In a phase I study increasing doses of the Ad-p53 gene were injected in the tumors of patients with advanced NSCLC who had progressed on conventional treatment (Swisher et al., 1999). Out of 25 patients two achieved a partial response, and 16 had stabilization of disease. p53 expression was detected in 12 patients. A subsequent study by the same group of investigators administered the Ad-p53 gene in conjunction with cisplatin to 24 patients with advanced lung cancer (Nemunaitis et al., 2000). Seventeen patients achieved an improvement or stable disease and two patients had partial response. However, no anti-tumor activity was observed in a small randomized trial involving a different $\mathrm{rAd} / \mathrm{p} 53$ product in patients with advanced non-small cell lung cancer (Schuler et al., 2001).

Clearly, as it stands right now, delivery of genes represents a major technical problem for gene therapy in general and in particular for lung cancer. In another study, bronchoalveolar lavage has been used as a delivery method in patients with bronchoalveolar carcinomas. These tumors are characterized by multifocal spread and are rather refractory to systemic chemotherapy and often not operable due to their extension. In this phase I trial Ad-p53 (RPR/INGN 201) was delivered via bronchoalveolar lavage (BAL) to involved lobes of the lung was performed in patients with BAC (Kubba et al., 2000. Grade 4 pulmonary toxicity was noted in one patient at the higher dose level reached $\left(2 \times 10^{10} \mathrm{vp}\right)$. After two cycles, pathological response was observed on biopsy in two patients out of nine evaluable. The study is still ongoing.

Ways of improving efficacy of gene transfer are the exploration of targeted gene delivery by coupling of receptor ligands to the vector (Frederiksen et al., 1999), liposomal p53 formulation (Zou et al., 1998) or the ONYX-015 virus, a selectively-replicating adenovirus (Khuri et al., 2000).

Two other approaches to gene therapy have been attempted: suicide gene therapy and immunopotentiation. Suicide gene therapy is the approach by which a gene encoding an enzyme that catalyzes conversion of a normally nontoxic prodrug administered systemically into a toxic substance is delivered to tumor cells (Roth and Cristiano, 1997; Blaese et al., 1994; Singhal and Kaiser, 1998). The most widely used gene delivered in this strategy is the herpes simplex virus thymidine kinase (HSV TK) gene. This enzyme converts the normally nontoxic nucleoside analogue gancyclovir into a toxic compound. Because the human thymidine kinase has a low affinity for gancyclovir, and therefore, only tumor cells that express high levels of HSV TK after gene transfer will suffer the toxic effects of the drug. Interestingly, cell kill also occurs in neighboring cells to those transfected, a phenomenon called 'bystander effect'. A phase I trial of adenoviral vector delivery of HSV TK followed by intravenous Gancyclovir is under way in advanced NSCLC (Human Gene Therapy Protocols, 1999).

Immunopotentiation approaches include the introduction of cytokine genes into tumor cells, transduction of tumor cells with genes that either augment major histocompatibility complex (MHC) class I presentation or provide co-stimulatory signals to enhance T-cell proliferation, and active vaccination with tumor 'specific' genes (Albelda, 1997).

The first type of approach has been explored in different trials in NSCLC. Nine patients received a single intra-tumoral injection of an adenovirus expressing the IL2 gene (rAd-IL2), showing no dose-limiting toxicity, but also no antitumor effect (Escudier et al., 2000). A phase I/II trial of antigen specific immunotherapy in patients with MUC-1 positive advanced NSCLC is ongoing using vaccinia-virus-MUC1-IL2 
(TG1031) (Human Gene Therapy Protocols, 1999). An alternative approach explored in phase $I$ is the vaccination with lethally irradiated autologous NSCLC cells engineered by adenoviral gene transfer to secrete human GM-CSF (GVAX). The results suggest that GVAX is feasible, well tolerated and may enhance anti-tumor immunity (Salgia et al., 2000). Moreover NSCLC is known to express carcinoembryogenic antigen in most of the cases (Conry et al., 1995). Based on that and on encouraging preclinical data (Halbert et al., 1995), a phase I of vaccination with tumor 'specific' gene CEA has been performed in patients with metastatic adenocarcinoma. Despite high doses $1 \times 10^{8}$ p.f.u.s, no dose-limiting toxicity was observed in this study (Albelda et al., 2000).

\section{Antisense therapy}

Antisense oligonucleotides are designed to complement a region of a particular gene or messenger RNA and serve as potential blockers of transcription or translation through sequence-specific hybridization (Stein and Narayanan, 1994; Askari and McDonnell, 1996). Therapeutic phosphorothioate oligodeoxynucleotides have a sulfur atom substituted for one of the phosphate oxygen atoms at a nonbridging position, which makes them nuclease resistant. They have also been extensively examined in vitro and have been targeted to the $b c r-a b l$ and $b c l-2$ messenger RNAs among others. Recently, phosphorothioate oligodeoxynucleotides have entered clinical trials with satisfactory tolerance in humans. Several antisense nucleotides have so far been developed and clinical trials performed. Yuen et al. (2001) recently completed phase I/II trial in which an antisense to PKC- $\alpha$ (ISIS 3521) was co-administered with carboplatin and paclitaxel to 53 patients with untreated advanced NSCLC mainly in stage IV disease. An overall response rate of $42 \%$ was reported and an impressive median survival of 19 months with a 1 year survival of $75 \%$. Toxicity of the antisense is very mild; however, due to the poor stability of these compounds, continuous intravenous infusion is necessary. In this study a continuous infusion via central venous access was given for 14 days. On the basis of these impressive preliminary findings, a phase III trial is comparing carboplatin and paclitaxel alone to the combination with ISIS 3521. Another trial identical in design is about to start in Europe with the combination of cisplatin-gemcitabine.

ISIS 2303, an antisense oligonucleotide against Ras has recently been tested in 24 second-line advanced NSCLC patients. No responses were observed in this study (Dang et al., 2001).

\section{Farnesyltransferase inhibition}

K-ras mutations are present in approximately $25-30 \%$ of adenocarcinomas (Rodenhuis and Slebos, 1990;
Schiller et al., 2001). More rarely K-ras mutations are observed in anaplastic carcinomas and are virtually absent in squamous cell carcinomas and in SCLC. Most mutations of the K-ras oncogene in NSCLC are at codon 12, 61, and 63. Mutated ras genes produce mutated proteins that remain locked in an activated state, thereby relaying uncontrolled proliferative signal growth (Rowinsky et al., 1999).

Farnesyltransferase is an enzyme required to transfer farnesyl isoprenoid to cytoplasmic Ras c-terminus, needed to anchor it to the cell membrane (Kohl et al., 1993). Farnesyltransferase catalyzes the farnesylation step by recognizing the CAAX motif of the Ras cterminus, and transferring a 15-carbon farnesyl isoprenoid from farnesyl diphosphate (FDP) to form a thioether bond with the ras cysteine (Rowinsky et al., 1999). There are several different classes of farnesyltransferase inhibitors (FTIs). Although various FTIs can clearly inhibit farnesylation of Ras, this event is neither necessary nor sufficient to cause the desired anticancer effects observed in preclinical in vivo models. In fact, the susceptibility of human tumor cells to FTIs does not correlate with Ras mutational status (SeppLorenzino et al., 1995).

Three major classes of FTIs have been identified. These include FDP analogues which compete with the substrate FDP for the farnesyl transferase; peptidomimetics which compete with the CAAX portion of Ras for farnesyl transferase, and agents which combine the features of both. Several different inhibitors are currently being evaluated clinically: L-778,123, R115777, BMS214662, and SCH 66336. Phase I studies have demonstrated that the drugs are generally well tolerated, with their major side effects being gastrointestinal toxicities such as nausea, vomiting, diarrhea, and anorexia, as well as fatigue, and rarely, myelosuppression (Zujewski et al., 2000; Eskens et al., 2001; Camacho et al., 2001). Phase II trials are ongoing in a number of tumor types (Winquist et al., 2001), alone and in combination with chemotherapy (Bailey et al., 2001; Holden et al., 2001; Piccart-Gebhart et al., 2001; Verweij et al., 2001; Verslype et al., 2001). Trials using FTIs with or without chemotherapy are underway in NSCLC. A large phase III study is about to start with carboplatin-paclitaxel with or without SCH 66336 in untreated NSCLC patients.

\section{Cyclo-oxygenase-2 inhibition}

The use of COX-2 inhibitors has some potential application to the prevention and therapy of lung cancer. Precursor lesions of lung cancer including atypical alveolar epithelium, atypical adenomatous hyperplasias and carcinoma in situ specimens express high levels of COX-2 (Hida et al., 1998a; Hosomi et al., 2000). COX-2 inhibitors, given also their relative lack of toxicity for prolonged periods of administration, deserve investigation in the chemopreventive setting.

COX-2 expression is high in well-differentiated lung adenocarcinomas, low in poorly differentiated adeno- 
carcinoma and squamous cell carcinomas and undetectable in SCLC (Hida et al., 1998a; Wolff et al., 1998). COX-2 overexpression has also been associated with worse prognosis in resected NSCLC patients (Achiwa et al., 1999). Aspirin, indomethacin, meloxocam and ibuprofen have been shown to decrease NSCLC growth in vitro whereas aspirin and indomethacin inhibited proliferation of NSCLC xenografts in nude mice (Hida et al., 1998b; Tsubouchi et al., 2000). Furthermore, inhibitors of cyclo-oxygenase and lipoxygenase act as modulators of cytotoxic cancer therapies (Teicher et al., 1994; Soriano et al., 1999). Clinical studies employing COX-2 inhibitors are just now getting underway. The studies will explore the use of COX-2 inhibitors with and without classic cytotoxic agents.

\section{Vaccines against SCLC}

An anti-idiotypic antibody against GD3 has been developed. GD3 is a ganglioside which is highly expressed on the cell membrane of cells of neuroendocrine origin, including neuronal derivation, melanoma and SCLC. The anti-idiotypic antibody is more immunogenic than the primary antibody, and has been called Bec2. With the addition of adjuvant BCG this vaccine has been tested in 15 patients with SCLC, in response after chemotherapy or chemotherapy and radiotherapy (Grant et al., 1999). The major toxicity of this vaccine is related to the presence of BCG, which leads to transient ulceration and sometimes fever. In general, because of the BCG, patients with a history of tuberculosis are excluded. The long-term survival especially of patients with limited disease, prompted the initiation of a large randomized study in which patients with limited disease are given chemo-radiation and then randomized to $\mathrm{Bec} / \mathrm{BCG}$ vaccination or follow-up. This large randomized study is approaching the targeted accrual of 500 patients. In the small pilot study, seven patients with limited disease had a survival which had not reached the median at a follow-up of 47 months. Apparently the longest survivors were patients who developed anti-GD3 antibodies.

Another vaccine against another cell surface ganglioside has also recently been tested in 10 SCLC patients who had achieved a major response to induction therapy. This Fucosyil-GM1-keyhole limpet hemocyanin conjugate vaccine was proven to be safe

\section{References}

Achiwa H, Yatabe Y, Hida T, Kuroishi T, Kozaki K, Nakamura S, Ogawa M, Sugiura T, Mitsudomi T and Takahashi T. (1999). Clin. Cancer Res., 5, 1001-1005. Albelda SM. (1997). Chest, 111, 114S-149S.

Albelda SM, Wiewrodt R and Zuckerman JB. (2000). Ann. Intern. Med., 132, 649-660.

Adlard JW. (2000). Anti-Cancer Drugs, 11, 787-791. and immunogenic, despite the recent chemotherapy and radiation (Dickler et al., 1999).

\section{Other targets}

CI-994 (N-acetyl dinaline) is a novel substituted benzamide derivative with cytotoxic activity in preclinical models (LoRusso et al., 1996). Although the precise mechanism of action is not completely understood, CI-994 appears to work with increase in acetylation of histones. No specific activity has been observed on DNA, RNA, protein or lipid byosynthesis. It is rapidly absorbed orally, and a phase I study with chronic daily administration identified thrombocytopenia as dose limiting toxicity. Gastrointestinal side effects and fatigue were also observed (Prakash et al., 2001). Several major responses were reported in phase I studies and phase II studies. A large phase III study is currently running which compares carboplatin-paclitaxel with and without CI-994.

Bexarotene (Targretin ${ }^{\mathrm{TM}}$, Ligand Pharmaceuticalsis) is a retinoid-X-receptor selective retinoid with preclinical antitumor activity in squamous cell cancers. In phase I studies of Bexarotene in patients with solid tumors, prolonged stabilizations were observed in a number of patients with advanced NSCLC, although no objective responses were achieved. The toxicity of this retinoid was mainly represented by hypertriglyceridemia, and reversible liver function disturbances (Rizvi et al., 1999). One study assessed in a phase III the combination of cisplatin-vinorelbine with Bexarotene; cisplatin and vinorelbine were given at $100 \mathrm{mg} / \mathrm{m}^{2}$ every 6 weeks and alternating doses of 30 and $15 \mathrm{mg} / \mathrm{m}^{2}$ every 2 weeks, respectively; bexarotene was escalated from 150 to $600 \mathrm{mg} / \mathrm{m}^{2}$. In total 43 patients were enrolled and 28 were given bexarotene $400 \mathrm{mg} / \mathrm{m}^{2}$ in the phase II part of the study (Khuri et al., 2001). In total eight patients responded (19\%), but the response rate was $25 \%$ in the phase II study. The toxicities observed were tolerable and expected based on the side effects of this chemotherapy regimen and single agent toxicity of bexarotene. A remarkable $61 \%$ 1 year survival was reported, which appears encouraging, considering that 26 out of 28 patients in the phase II part of the study had stage IV disease. However, this is a small phase II study and one has to be cautious in generalizing these results. A phase III study has been planned.
Arteaga CL, Winnier AR, Poirier MC, Lopez-Larraza DM, Shawver LK, Hurd SD and Stewart SJ. (1994). Cancer Res., 54, $3758-3765$.

Arteaga CL. (2001). J. Clin. Oncol., 19, 32s-40s.

Askari FK and McDonnell WM. (1996). N. Engl. J. Med., 334, 316-318.

Averbuch SD. (2002). Clin. Cancer Res., 8, 1-3. 
Bailey HH, Marnocha R, Arzoomanian R, Alberti D, Binger $\mathrm{K}$, Vlokman $\mathrm{J}$, Feierabend $\mathrm{C}$, Ellingen S, Black S, Hampton K, Cooper M, Hott T and Wilding G. (2001). Proc. Am. Soc. Clin. Oncol., 20, 79a.

Baselga J, Norton L, Albanell J, Kim YM and Mendelsohn J. (1998). [published erratum appears in Cancer Res 1999 Apr 15;59(8):2020]. Cancer Res., 58, 2825-2831.

Baselga $\mathbf{J}$ and Averbuch SD. (2000). Drugs, 60, 33-40. discussion $41-32$.

Baselga J, Pfister D, Cooper MR, Cohen R, Burtness B, Bos M, D'Andrea G, Seidman A, Norton L, Gunnett K, Falcey J, Anderson V, Waksal H and Mendelsohn J. (2000). J. Clin. Oncol., 18, $904-914$.

Baselga J, Yano S and Giaccone G et al. (2001). Clin. Cancer Res., 7, (Suppl 11): 630a.

Bauer KS, Dixon SC and Figg WD. (1998). Bioch. Pharmacol., 55, 1827-1834.

Blaese RM, Ishii-Morita H, Mullen C, Ramsey J, Ram Z, Oldfield E and Culver K. (1994). Eur. J. Cancer, 30A, $1190-1193$

Blanke CD, von Mehren $\mathrm{M}$, Joensuu $\mathrm{H}$, Roberts $\mathrm{PJ}$, Eisneberg B, Heinrich M, Drucker B, Tuveson D, Dimitrijevic S, Silberman SL and Demetri GD. (2001). Proc. Am. Soc. Clin. Oncol., 20, 1 a.

Bos M, Mendelsohn J, Kim YM, Albanell J, Fry DW and Baselga J. (1997). Clin. Cancer Res., 3, 2099-2106.

Brown PD, Bloxidge RE, Stuart NS, Gatter KC and Carmichael J. (1993). J. Natl. Cancer Inst., 85, 574-578.

Camacho LH, Soignet SL, Pezzulli S, Canales C, Aghajanian C, Spriggs DS, Damle B and Sonnichsen D. (2001). Proc. Am. Soc. Clin. Oncol., 20, 79a.

Carbone DC. (1997). Semin. Oncol., 24, 388-401.

Carpenter G. (1987). Ann. Rev. Biochem., 56, 881-914.

Carpenter G and Cohen S. (1990). J. Biol. Chem., 265, $7709-$ 7712.

Chambers AF and Matrisian LM. (1997). J. Natl. Cancer Inst., 89, $1260-1270$.

Chen C, Parangi S, Tolentino MJ and Folkman J. (1995). Cancer Res., 55, 4230-4233.

Ciardiello F, Caputo R, Bianco R, Damiano V, Pomatico G, De Placido S, Bianco AR and Tortora G. (2000). Clin. Cancer Res., 6, 2053-2063.

Clarke MR, Landreneau RJ, Finkelstein SD, Wu TT, Ohori P and Yousem SA. (1997). Human Pathol., 28, 54-59.

Cohen RB, Falcey JW, Paulter VJ, Fetzer KM and Waksal HW. (2000). Proc. Am. Soc. Clin. Oncol., 19, 474a.

Conry RM, LoBuglio A, Loechel F, Moore SE, Sumerel LA, Barlow DL and Curiel DT. (1995). Hum. Gene Ther., 2, $59-65$.

DeVore RF, Fehrenbacher L, Herbst RS, Langer CJ, Kelly K, Gaudreault J, Holmgren E, Novotny WF and Kabbinavar F. (2000). Proc. Ann. Meet. Am. Soc. Clin. Oncol., 19, 485a.

Dang T, Johnson D, Kelly K, Rizvi N, Holmlund J and Dorr A. (2001). Proc. Am. Soc. Clin. Oncol., 20, 332a.

Dickler MN, Ragupathi G, Liu NX, Musselli C, Martino DJ, Miller VA, Kris MG, Brezicka FT, Livingston PO and Grant SC. (1999). Clin. Cancer Res., 5, 2773-2779.

Druker BJ, Sawyers CL, Kantarjian H, Resta DJ, Reese SF, Ford JM, Capdeville R and Talpaz M. (2001a). N. Engl. J. Med., 344, $1038-1042$.

Druker BJ, Talpaz M, Resta D, Peng B, Buchdunger E, Ford JM, Lydon NB, Kantarjian H, Capdeville R, Ohno-Jones S and Sawyers CL. (2001b). N. Engl. J. Med., 344, 10311037.

Ennis B, Valverius E, Bates S, Lippman M, Bellot F, Kris R, Schlessinger J, Masui H, Goldenberg A and Mendelsohn J. (1989). Mol. Endocrinol., 3, 1830-1838.

Escudier B, Le Chevalier T and Angevin F et al. (2000). Lung Cancer, 29, (Supp 1): 184 (abstract 622).

Eskens FA, Awada A, Cutler DL, de Jonge MJ, Luyten GP, Faber MN, Statkevich P, Sparreboom A, Verweij J, Hanauske AR and Piccart M European Organization for Research Treatment of Cancer Early Clinical Studies Group. (2001). J. Clin. Oncol., 19, 1167-1175.

Fan Z, Baselga J, Masui H and Mendelsohn J. (1993). Cancer Res., 53, 4637-4642.

Ferrara N and Bunting S. (1996). Curr. Opin. Nephrol. Hyperten., 5, 35-44.

Ferrara N. (1999). J. Mol. Med., 77, 527-543.

Figlin RA, Belldegrun A, Lohner ME, Roskos L, Yang X, Schwab G and Weiner LM. (2001). Proc. Am. Soc. Clin. Oncol., 20, 276a.

Folkman J. (1995). N. Engl. J. Med., 333, 1757-1763.

Fong TA, Shawver LK, Sun L, Tang C, App H, Powell TJ, Kim YH, Schreck R, Wang X, Risau W, Ullrich A, Hirth KP and McMahon G. (1999). Cancer Res., 59, 99- 106.

Forgacs E, Zochbauer-Muller S, Olah E and Minna JD. (2001). Pathol. Oncol. Res., 7, 6-13.

Frederiksen KS, Petri A, Abrahamsen N and Poulsen HS (1999). Lung Cancer, 23, 191-207.

Gatzemeier U, Groth G and Hirsh V. (2001). Eur. J. Cancer, 37, (Suppl 6): S50 (abstract 173).

Giatromanolaki A, Koukourakis MI, O'Byrne K, Kaklamanis L, Dicoglou C, Trichia E, Whitehouse R, Harris AL and Gatter KC. (1996). Anticancer Res., 16, 3819-3825.

Good DJ, Polverini PJ, Rastinejad F, Le Beau MM, Lemons RS, Frazier WA and Bouck NP. (1990). Proc. Natl. Acad. Sci. USA, 87, 6624-6628.

Gordan MS, Talpaz M, Margolin K, Holmgren E, Sledge GW, Benjamin R, Stalter S, Sahk S and Adelman D. (1998). Proc. Annu. Meet. Am. Soc. Clin. Oncol., 17, 210a.

Grant SC, Kris MG, Houghton AN and Chapman PB. (1999). Clin. Cancer Res., 5, 1319-1323.

Guddo F, Fontanini G, Reina C, Vignola AM, Angeletti A and Bonsignore G. (1999). Human Pathol., 30, 788- 794.

Halbert CL, Alexander IE, Wolgamot GM and Miller AD. (1995). J. Virol., 69, 1473-1479.

Herbst RS, Kim ES and Harari PM. (2001). Expert. Opin. Biol. Ther., 1, 719-732.

Hida T, Yatabe Y, Achiwa H, Muramatsu H, Kozaki K, Nakamura S, Ogawa M, Mitsudomi T, Sugiura T and Takahashi T. (1998a). Cancer Res., 58, 3761-3764.

Hida T, Leyton J, Makheja AN, Ben-Av P, Hla T, Martinez A, Mulshine J, Malkani S, Chung P and Moody TW. (1998b). Anticancer Res., 18, 775-782.

Hidalgo M, Malik S, Rowinsky E, Miller A, Duffey D, de'Grafenried L, Siu L, Simmons C, Kreisberg J and Brattain M. (2001). Proc. Am. Soc. Clin. Oncol., 20, 71a.

Holden SN, Eckhardt S, Fisher S, Persky M, Mikule C, O'Bryant CL, Morrow M, Richards H, Rodriguez S, Bol C and Cohen R. (2001). Proc. Am. Soc. Clin. Oncol., 20, 80a.

Hosomi Y, Yokose T, Hirose Y, Nakajima R, Nagai K, Nishiwaki Y and Ochiai A. (2000). Lung Cancer, 30, $73-$ 81 .

Human Gene Therapy Protocols. (1999). Hum. Gene Ther., 10, 2037-2088.

Ichimura E, Maeshima A, Nakajima T and Nakamura T. (1996). Jpn. J. Cancer Res., 87, $1063-1069$. 
Johnson D, DeVore R, Kabbinavar F, Herbst R and Holmgren E and Novotny W. (2001). Proc. Am. Soc. Clin. Oncol., 20, 315a.

Kenyon BM, Browne F and D'Amato RJ. (1997). Exp. Eye Res., 64, 971-978.

Kern JA, Schwartz DA, Nordberg JE, Weiner DB, Greene MI, Torney L and Robinson RA. (1990). Cancer Res., 50, $5184-5188$.

Kern JA, Slebos RJ, Top B, Rodenhuis S, Lager D, Robinson RA, Weiner D and Schwartz DA. (1994). J. Clin. Invest., 93, 516-520.

Khuri FR, Nemunaitis J, Ganly I, Arseneau J, Tannock IF, Romel L, Gore M, Ironside J, MacDougall RH, Heise C, Randlev B, Gillenwater AM, Bruso P, Kaye SB, Hong WK and Kirn DH. (2000). Nat. Med., 6, 879-885.

Khuri FR, Rigas JR, Figlin R, Gralla RJ, Shin DM, Munden R, Fox N, Huyghe MR, Kean Y, Reich SD and Hong WK. (2001). J. Clin. Oncol., 19, 2626.

Kim YC, Park KO, Kern JA, Park CS, Lim SC, Jang AS and Yang JB. (1998). Lung Cancer, 22, $181-190$.

Klapper LN, Glathe S, Vaisman N, Hynes NE, Andrews GC, Sela M and Yarden Y. (1999). Proc. Natl. Acad. Sci. USA, 96, 4995-5000.

Kohl NE, Mosser SD, deSolms SJ, Giuliani EA, Pompliano DL, Graham SL, Smith RL, Scolnick EM, Oliff A and Gibbs JB. (1993). Science, 260, 1934-1937.

Kris MG, Herbst R, Rischin D, LoRusso P, Baselga J, Hammond L, Feyereislova A, Ochs J and Averbuch S. (2000). Lung Cancer, 29, (Suppl 1): 72.

Krug LM, Miller VA, Crapanzano J, Ng KK, Pizzo B, Tyson L, McClean N, Azzoli CG, Heelan RT, Ginsberg M, Venkatraman E and Kris MG. (2001). Proc. Am. Soc. Clin. Oncol., 20, 333a.

Kubba S, Schiller J, Slovis B, Coffee K, Worrell J, Thet L, Adak S, Mehta M, Johnson DH and Carbone D. (2000). Proc. Am. Soc. Clin. Oncol., 19, 487a.

Kuenen BC, Rosen L, Smit EF, Parson MR, Levi M, Ruijter R, Huisman H, Kedde MA, Noordhuis P, van der Vijgh WJ, Peters GJ, Cropp GF, Scigalla P, Hoekman K, Pinedo HM and Giaccone G. (2002). J. Clin. Oncol., 20, 14461448.

Langer CJ, Adak S, Thor A, Vangel M and Johnson DH. (2001). Proc. Am. Soc. Clin. Oncol., 20, 315a.

Levitzki A and Gazit A. (1995). Science, 267, 1782-1788.

LoRusso PM, Demchick L, Foster B, Knight J, Bissery MC, Polin LM, Leopold IIIWR and Corbett TH. (1996). Invest. New Drugs, 14, 349 - 356.

Margolin K, Gordon MS, Talpaz M, Fyfe G, Novotny W, Adelman D and Breed J. (1999). Proc. Annu. Meet. Am. Soc. Clin. Oncol., 18, 435a.

Mendel DB, Laird AD, Smolich BD, Blake RA, Liang C, Hannah AL, Shaheen RM, Ellis LM, Weitman S, Shawver LK and Cherrington JM. (2000). Anti-Cancer Drug Design, 15, $29-41$.

Negoro S, Nakagawa K, Fukuoka M, Kudoh S, Tamura T, Yoshimura N, Takeda K, Tanigawara Y and Swaisland H. (2001). Proc. Am. Soc. Clin. Oncol., 20, 324a.

Nelson AR, Fingleton B, Rothenberg ML and Matrisian LM. (2000). J. Clin. Oncol., 18, 1135-1149.

Nemunaitis J, Klemow S, Tong A, Courtney A, Johnston W, Mack M, Taylor W, Solano M, Stone M, Mallams J and Mues G. (1998). J. Clin. Oncol., 21, 155-160.
Nemunaitis J, Swisher SG, Timmons T, Connors D, Mack M, Doerksen L, Weill D, Wait J, Lawrence DD, Kemp BL, Fossella F, Glisson BS, Hong WK, Khuri FR, Kurie JM, Lee JJ, Lee JS, Nguyen DM, Nesbitt JC, Perez-Soler R, Pisters KM, Putnam JB, Richli WR, Shin DM and Walsh GL. (2000). J. Clin. Oncol., 18, 609-622.

Nguyen DM, Wiehle SA, Koch PE, Branch C, Yen N, Roth JA and Cristiano RJ. (1997). Cancer Gene Ther., 4, $191-$ 198.

Noda K, Nishiwaki Y, Kawahara M, Negoro S, Sugiura T, Yokoyama A, Fukuoka M, Mori K, Watanabe K, Tamura T, Yamamoto S and Saijo N The Japan Clinical Oncology Group. (2002). N. Engl. J. Med., 346, 85-91.

O-Charoenrat P, Rhys-Evans P, Modjtahedi H, Court W, Box G and Eccles S. (2000). Int. J. Cancer, 86, 307-317.

Olivero M, Rizzo M, Madeddu R, Casadio C, Pennacchietti S, Nicotra MR, Prat M, Maggi G, Arena N, Natali PG, Comoglio PM and Di Renzo MF. (1996). Br. J. Cancer, 74, $1862-1868$.

O'Reilly MS, Holmgren L, Shing Y, Chen C, Rosenthal RA, Moses M, Lane WS, Cao Y, Sage EH and Folkman J. (1994). Cell, 79, 315-328.

O'Reilly MS, Boehm T, Shing Y, Fukai N, Vasios G, Lane WS, Flynn E, Birkhead JR, Olsen BR and Folkman J. (1997). Cell, 88, 277-285.

Parsons SL, Watson SA, Brown PD, Collins HM and Steele RJ. (1997). Br. J. Surg., 84, $160-166$.

Perez-Soler R, Shin DM, Donato N, Radinsky R, Khuri F, Glisson BS, Shin H, Matsumoto T, Lawhorn K, Waksal H and Hong WK. (1998). Proc. Am. Soc. Clin. Oncol., 17, 1514.

Perez-Soler R, Chachoua A, Huberman M, Karp D, Rigas J, Hammond L, Rowinsky E, Preston G, Ferrante KJ, Allen LF, Nadler PI and Bonomi P. (2001). Proc. Am. Soc. Clin. Oncol., 20, 310a.

Piccart-Gebhart MJ, Branle F, de Valeriola D, Dubuisson M, Hennebert P, Gil T, Forget F, Seifert W, Thibault A, Bol C and Awada A. (2001). Proc. Am. Soc. Clin. Oncol., 20, 80a.

Pietras RJ, Fendly BM, Chazin VR, Pegram MD, Howell SB and Slamon DJ. (1994). Oncogene, 9, 1829-1838.

Pietras RJ, Poen JC, Gallardo D, Wongvipat PN, Lee HJ and Slamon DJ. (1999). Cancer Res., 59, 1347 - 1355.

Prakash S, Foster BJ, Meyer M, Wozniak A, Heilbrun LK, Flaherty L, Zalupski M, Radulovic L, Valdivieso M and LoRusso PM. (2001). Invest. New Drugs, 19, 1-11.

Rizvi NA, Marshall JL, Dahut W, Ness E, Truglia JA, Loewen G, Gill GM, Ulm EH, Geiser R, Jaunakais D and Hawkins MJ. (1999). Clin. Cancer Res., 5, 1658 - 1664.

Rodenhuis S and Slebos RJC. (1990). Am. Rev. Respir. Dis., 142, S27-S30.

Rosen L, Mulay M, Mayers A, Kabbinavar F, Rosen P, Cropp G and Hannah A. (1999). Proc. Am. Soc. Clin. Oncol., 18, 161a.

Roth JA, Nguyen D, Lawrence DD, Kemp BL, Carrasco CH, Ferson DZ, Hong WK, Komaki R, Lee JJ, Nesbitt JC, Pisters KM, Putnam JB, Schea R, Shin DM, Walsh GL, Dolormente MM, Han CI, Martin FD, Yen N, Xu K, Stephens LC, McDonnell TJ, Mukhopadhyay T and Cai D. (1996). Nat. Med., 2, 985-991.

Roth JA and Cristiano RJ. (1997). J. Natl. Cancer Inst., 89, $21-39$. 
Rowinsky EK, Windle JJ and Von Hoff DD. (1999). J. Clin. Oncol., 17, 3631-3652.

Salgia R, Lynch TJ and Skarin AT et al. (2000). Lung Cancer, 29, (Suppl 1): 186 (abstract 626).

Salomon DS, Brandt R, Ciardiello $\mathrm{F}$ and Normanno N. (1995). Crit. Rev. Oncol/Hematol., 19, 183-232.

Schiller JH, Adak S, Feins RH, Keller SM, Fry WA, Livingston RB, Hammond ME, Wolf B, Sabatini L, Jett J, Kohman L and Johnson DH. (2001). J. Clin. Oncol., 19, $448-457$.

Schuler M, Herrmann R, De Greve JL, Stewart AK, Gatzemeier U, Stewart DJ, Laufman L, Gralla R, Kuball J, Buhl R, Heussel CP, Kommoss F, Perruchoud AP, Shepherd FA, Fritz MA, Horowitz JA, Huber C and Rochlitz C. (2001). J. Clin. Oncol., 19, 1750-1758.

Sepp-Lorenzino L, Ma Z, Rands E, Kohl NE, Gibbs JB, Oliff A and Rosen N. (1995). Cancer Res., 55, 5302 - 5309.

Shawver LK. (1999). Tyrosine kinase inhibitors: from the emergence of targets to their clinical development In American Society of Clinical Oncology Educational Book Perry MC (ed). Lippincott, Williams \& Wilkins: Alexandria VA, pp. 29-47.

Shepherd FA, Giaccone G, Debruyne C, Hirsh V, Smylie M, Rubin S, Martins H, Lamont A, Krazkowski M, Zee B, Sadura A and Seymour L. (2001). Proc. Am. Soc. Clin. Oncol., 20, 4a.

Shin DM, Nemunaitis J, Zinner RG, Donato N, Shin HJ, Myers J, Zhang P, Zengraft R, Khuri FR, Glisson BS, Eiseman I, Olson S, Bycott P, Lenehan PF and Hong WK. (2001). Proc. Am. Soc. Clin. Oncol., 20, 82a.

Singhal S and Kaiser LR. (1998). Surg. Oncol. Clin. N. Am., 7, $505-536$

Singhal S, Mehta J, Desikan R, Ayers D, Roberson P, Eddlemon P, Munshi N, Anaissie E, Wilson C, Dhodapkar M, Zeddis J and Barlogie B. (1999). N. Engl. J. Med., 341, $1565-1571$

Sirotnak FM, Zakowski MF, Miller VA, Scher HI and Kris MG. (2000). Clin. Cancer Res., 6, 4885-4892.

Smolich BD, Yuen HA, West KA, Giles FJ, Albitar M and Cherrington JM. (2001). Blood, 97, 1413-1421.

Smylie M, Mercier R, Aboulafia D, Tucker R, Bonomi P, Collier M, Keller M, Stuart-Smith J, Knowles M, Clendeninn NJ and Shepherd F. (2001). Proc. Am. Soc. Clin. Oncol., 20, 307a.

Soriano AF, Helfrich B, Chan DC, Heasley LE, Bunn Jr PA and Chou TC. (1999). Cancer Res., 59, 6178-6184.

Stein CA and Narayanan R. (1994). Curr. Opin. Oncol., 6, $587-594$.

Stetler-Stevenson WG, Hewitt R and Corcoran M. (1996). Sem. Cancer Biol., 7, 147-154.

Swisher SG, Roth JA, Nemunaitis J, Lawrence DD, Kemp BL, Carrasco CH, Connors DG, El-Naggar AK, Fossella F, Glisson BS, Hong WK, Khuri FR, Kurie JM, Lee JJ, Lee JS, Mack M, Merritt JA, Nguyen DM, Nesbitt JC, Perez-Soler R, Pisters KM, Putnam Jr JB, Richli WR, Savin M and Waugh MK. (1999). J. Natl. Cancer Inst., 91, $763-771$
Teicher BA, Korbut TT, Menon K, Holden SA and Ara G. (1994). Cancer Chemother. Pharmacol., 33, 515-522.

Thomas DA and Kantarjian HM. (2000). Curr. Opin. Oncol., 12, $564-573$.

Traxler P, Buchdunger E, Furet P, Gschwind H-P, Ho P, Mett H, O'Reilly T, Pfaar U and Thomas H. (1999). Clin. Cancer Res., 5, 3750S.

Tsai CM, Chang KT, Perng RP, Mitsudomi T, Chen MH, Kadoyama C and Gazdar AF. (1993). J. Natl. Cancer Inst., 85, $897-901$.

Tsai CM, Yu D, Chang KT, Wu LH, Perng RP, Ibrahim NK and Hung MC. (1995). J. Natl. Cancer Inst., 87, 682-684.

Tsubouchi Y, Mukai S, Kawahito Y, Yamada R, Kohno M, Inoue K and Sano H. (2000). Anticancer Res., 20, $2867-$ 2872

Verslype C, Van Steenbergen W, Humblet Y, Marse H, De Vis J, Palmer P, Seifert W, Bol C and Van Cutsem E. (2001). Proc. Am. Soc. Clin. Oncol., 20, 171a.

Verweij J, Kehrer D, Planting A, de Jonge M, Eskens F, Klaren A, De Heus G, Palmer P, Bol C and Sparreboom A. (2001). Proc. Am. Soc. Clin. Oncol., 20, 81 a.

Wang WL, Healy ME, Sattler M, Verma S, Lin J, Maulik G, Stiles CD, Griffin JD, Johnson BE and Salgia R. (2000). Oncogene, 19, 3521-3528.

Winquist E, Moore MJ, Chi K, Ernst S, Hirte H, Iscoe N, Venner P, Huan S, Powers J, Seymour L and Boucher T. (2001). Proc. Am. Soc. Clin. Oncol., 20, 197a.

Wolff H, Saukkonen K, Anttila S, Karjalainen A, Vainio H and Ristimaki A. (1998). Cancer Res., 58, 4997-5001.

Yang X, Jia X, Corvalan JR, Wang P and Davis CG. (2001). Crit. Rev. Oncol. Hematol., 38, 17-23.

Yarden Y and Ullrich A. (1988). Ann. Rev. Biochem., 57, $443-478$

Yu D, Wang SS, Dulski KM, Tsai CM, Nicolson GL and Hung MC. (1994). Cancer Res., 54, 3260-3266.

Yuen A, Halsey J, Fisher G, Advani R, Moore M, Saleh M, Ritch P, Harker G, Ahmed F, Jones C, Polikoff J, Keiser W, Kwoh TJ, Holmlund J, Dorr A and Sikic B. (2001). Proc. Am. Soc. Clin. Oncol., 20, 309a.

Zeng-Rong N, Paterson J, Alpert L, Tsao MS, Viallet $\mathbf{J}$ and Alaoui-Jamali MA. (1995). Cancer Res., 55, 4760-4764.

Zou Y, Zong G, Ling YH, Hao MM, Lozano G, Hong WK and Perez-Soler R. (1998). J. Natl. Cancer Inst., 90, 1130 1137.

Zujewski J, Horak ID, Bol CJ, Woestenborghs R, Bowden C, End DW, Piotrovsky VK, Chiao J, Belly RT, Todd A, Kopp WC, Kohler DR, Chow C, Noone M, Hakim FT, Larkin G, Gress RE, Nussenblatt RB, Kremer AB and Cowan KH. (2000). J. Clin. Oncol., 18, $927-941$. 